\title{
IDENTIFYING IMPORTANT AREAS FOR ORCHID CONSERVATION IN CRETE
}

\section{SPYROS TSIFTSIS ${ }^{1, *}$, IOANNIS TSIRIPIDIS ${ }^{1}$, and PANAYIOTIS TRIGAS ${ }^{2}$}

\author{
${ }^{1}$ Department of Botany, School of Biology, Aristotle University of Thessaloniki, GR-54124 Thessaloniki, Greece \\ ${ }^{2}$ Laboratory of Systematic Botany, Department of Agricultural Biotechnology, Agricultural University of Athens, \\ GR-11855 Athens, Greece \\ *Corresponding author: stsiftsi@bio.auth.gr; Tel.: +30 2510244444; Fax: +30 2510243711
}

\begin{abstract}
Crete is especially rich in orchids and their distribution is well known and documented by many floristic accounts. This information, however, is yet to be used to set conservation plans and priorities. We used MaxEnt incorporating both published and unpublished distribution data together with environmental variables to predict the potential distribution of orchids on Crete. The resulting probabilistic maps of species occurrence were used to identify the important areas for orchid conservation on the island. Sites prioritization was performed by applying a species weighting scheme, which was based on species niche breadth. The existence of ecological patterns determining site prioritization was determined using a regression tree analysis based on environmental variables and scores derived from Zonation analysis. The high importance sites were found on Mts Thripti, Ida and Lefka Ori, as well as at low altitude areas east of Heraklion and at the easternmost part of the island. Most of the variation in the site scores was explained by geological substrate, latitude and altitude. Based on the regression tree analysis, sites with the highest scores were at medium and high altitude areas, which are located at the interior of the island. These areas have soils mainly derived from limestones, ophiolites and deposits of calcareous rocks. The lack of a significant effect of vegetation type in explaining the distribution of high importance areas highlights the need for the establishment of micro-reserves for the conservation of orchids in Crete. Finally, endangered orchid species in need of specific conservation actions are indicated.
\end{abstract}

Keywords: conservation, orchids, species distribution models, place prioritization, regression trees

\section{Introduction}

Spatial conservation prioritization has much to offer in the field of biodiversity conservation as it can identify areas most in need of conservation action (Ferrier and Wintle 2009; Wilson et al. 2009). With a spate of quantitative techniques and tools that have recently come into use, more complicated data can be analyzed and as a result more sophisticated analyses can be performed. However, conservation prioritization software packages that have been developed as decision-support tools vary significantly. These packages can be based on relatively simple algorithms (e.g. ResNet; Garson et al. 2002) or more sophisticated algorithms, such as MARXAN (Ardron et al. 2008; Game and Grantham 2008) and Zonation (Moilanen et al. 2005; Moilanen 2007). The use of such software can provide robust solutions concerning landscape prioritization for conservation purposes. However, the results of the majority of such software are based on the quality and completeness of species (or other biodiversity surrogates) distribution data (Margules and Pressey 2000; Williams et al. 2002).

Species distribution data are in most cases available in the form of point location data, which in turn are usually geographically sparse. This kind of data can not only include many errors of omission, but are also often biased in their sampling towards more accessible areas (Elith and Leathwick 2009). Consequently, robust modelling techniques have been developed to overcome data scarcity, which can result in unreliable prioritization of the studied landscape. These methods use the relationship between the known species distribution and environmental conditions to predict the potential distribution of species in the form of a continuous occurrence probability map (Guisan et al. 2002; Pawar et al. 2007).

Species distribution data derived using modelling techniques have been increasingly used over the past years in identifying high value areas (e.g. hotspots of species richness, high ranking areas) (Pawar et al. 2007; Girardello et al. 2009). Furthermore, valuable information could also be provided by the investigation of the factors (e.g. environmental variables) that drive spatial arrangement of high diversity or conservation value areas. Furthermore, this can facilitate the investigation of differences in prioritization of areas using different biodiversity surrogates. Although the relationship between environmental variables and modelled species distribution has been extensively investigated at the community level (Peppler-Lisbach and Schröder 2004; Ferrier and Guisan 2006; Ferrier et al. 2009), it has been rarely used in the past to explain the spatial arrangement of high conservation value areas (Gelfand et al. 2005).

The orchid family, with approximately 25,000 species (Chase et al. 2003), is an important group with respect to conservation biology (Pillon and Chase 2006), being at the front line of extinction (Swarts and Dixon 2009). The susceptibility of orchids to conservation issues pertains to their complex biology (Rasmussen 1995; van der Cingel 
1995), their sensitivity to environmental changes (Vakhrameeva et al. 2008), as well as their high extinction risk, compared to species of other plant families (Hutchings 1989; Kull et al. 2006).

Crete is especially rich in orchids (Kretzschmar et al. 2002) with a significant proportion of them being geographically restricted (either they are endemic to Crete or restricted to the Aegean Archipelago). The first explorations of orchid flora on the island were performed early in the 20th century (e.g. Fleischmann 1925; Renz 1930, 1932), whereas recently, many researchers visit Crete every year to find and record orchids. Furthermore, new taxa have been identified and described in the last few years (e.g. Kalopissis and Robatsch 1980), increasing the number of species recorded on the island.

The orchids of Crete and their distribution are well known and documented by many floristic studies (e.g. Kreutz 1990; Manuel 1996). Among these species, some are narrow endemics (e.g. Cephalanthera cucullata, Ophrys fusca subsp. thriptiensis), while others are severely threatened by human activities. Two species endemic to Crete have been included in the recently published Red Data Book of Rare and Threatened Plants of Greece (Alibertis and Avramakis 2009a,b) and their distribution and conservation status have been documented, while such information for some other Cretan orchids is scant in the literature.

By utilizing all the available knowledge of orchid distribution on Crete, we aim to provide a prioritization of important sites for orchid diversity to guide orchid conservation efforts. In order to avoid sampling effort bias and to enrich species distribution data, we applied a species distribution modelling technique and its results are used in place prioritization. Finally, we investigated the dependence of conservation significant areas on certain ecological factors to identify the ecological patterns determining place prioritization.

\section{Materials and Methods}

\section{Study site}

The study area comprises the island of Crete and some associated nearby islets (e.g. Gavdos, Chrysi, Koufonisi and Dia) in South Aegean Sea. Crete is the fifth largest island of the Mediterranean Basin and the largest of the Greek Isles, with an area of $8729 \mathrm{~km}^{2}$. It is very mountainous, with the highest summits similar in altitude (Pachnes, the highest summit, reaches $2453 \mathrm{~m}$ ) to the majority of those on the Greek mainland (Phitos et al. 1995). The orchid flora of the study area consists of 69 taxa according to Kretzschmar et al. (2002) and supplementary data (Manuel 1996; Thiele and Thiele 2010). The climate of Crete is typically Mediterranean with mild, wet winters and hot, dry summers. Rainfall is mostly during autumn and winter and is unevenly distributed, with the western and northern slopes of Lefka Ori receiving c. $1800 \mathrm{~mm}$ per year, while the south-eastern coast around $300 \mathrm{~mm}$ (Strid and Tan 1997).

Geologically, Crete comprises the southernmost extension of the Hellenide mountain chain that formed during the late Tertiary convergence between the European and African plates. Limestones, phyllites and flyschs are the main bedrock types of the island, while marine, lacustrine and terrestrial deposits dominate in the lowlands (Mountrakis 1985; I.G.M.E. 1983). The vegetation of Crete has long been profoundly influenced by man and domestic animals and as a result is a complex mosaic of natural, semi-natural and man-made vegetation. Lowland areas are dominated by phrygana and macchie formations. Phrygana (open dwarf scrub dominated by low, often cushion-shaped shrubs) covers c. $25 \%$ of Crete from sea level up to $1500 \mathrm{~m}$ a.s.l. in the south, while macchie (dense scrub vegetation largely composed by hard-leaved evergreen species) covers c. $8 \%$ of the low and mid-altitudes of the island. Woodlands, which are mainly confined to mountainous areas, cover only c. $6-7 \%$ of Crete, while above the tree-line, low prickly scrub formations or communities of spiny cushion-shaped dwarf shrubs are present. Mountainous areas also include a variety of habitats such as cliffs, screes and karstic depressions (dolines) that host a significant number of plant species (Barbero and Quézel 1980; Zaffran 1990; Dimopoulos et al. 1997; Vogiatzakis et al. 2003).

\section{Species distribution data}

Species distribution data were obtained from Kretzschmar et al. (2002), Manuel (1996), Thiele and Thiele (2010), and unpublished records from several researchers (see acknowledgments), while the nomenclature follows Bateman et al. (1997), Kretzschmar et al. (2002) and Kreutz (2004). In total, the data set comprised of 24,950 records, from 68 of the 69 orchid species occurring in Crete. All the records were geo-referenced prior to the application of species distribution models and for the ones referring to grid cells of $1 \times 1 \mathrm{~km}$ size, the coordinates of grids' centroid were used.

The geographical distribution of the orchids was predicted by applying ecological niche models generated by MaxEnt software version 3.3.3 (Phillips et al. 2006; Pearson et al. 2007; Phillips and Dudík 2008). MaxEnt is considered as an appropriate technique in modelling species distributions, even with very small sample sizes (Elith et al. 2006; Pearson et al. 2007; Elith and Leathwick 2009). Furthermore, it is preferable for conservation purposes, because although it generates high omission errors or false negative rates, it can simultaneously avoid commission errors (Anderson et al. 2003; Loiselle et al. 2003; Phillips et al. 2006). MaxEnt estimates species distribution based on presence-only occurrence data, by using the maximum entropy principle and computes a probability distribution based on environmental variables 
spread over the entire study area. One taxon (Anacamptis palustris subsp. elegans) was excluded from distribution modelling, as it occurs in wet meadows, a habitat type with restricted distribution, which is not included in vegetation maps.

Initially, 24 environmental variables were selected as predictors in species distribution modelling. Nineteen of these were bioclimatic variables, while the other five were altitude, Euclidean distance of each grid cell from the nearest coast, heat load index, vegetation type and geological substrate. The bioclimatic variables and altitude were obtained from the WorldClim database (Hijmans et al. 2005) in a 30-sec resolution (approximately $1 \mathrm{~km}^{2}$ ). The vegetation layer was obtained by digitizing the vegetation maps of the local Forest Service. Heat load index was calculated on the basis of the aspect of each grid cell according to the formula provided by Neitlich and McCune (1997) and McCune and Keon (2002). The Euclidean distance and the aspect of each grid cell were determined using spatial analyst tools for ArcGIS 9.3 (Anon 2008) and an altitude raster layer. Geological data were obtained from the geological map of Greece at a scale of $1: 500,000$ (I.G.M.E. 1983). Vegetation type and geological substrate shapefile layers were converted in raster format at the same resolution.

To account for multicollinearity between the continuous environmental variables, we calculated Pearson correlation coefficients for all pairwise interactions using the ENMTools package (Warren et al. 2010). To eliminate correlated variables, only one (that which was more easily, intuitively interpretable) among any pair of those with a correlation coefficient $r>|0.75|$ was selected.

For each taxon, we ran 10 models with MaxEnt using the auto-features mode and the default settings, as suggested by Phillips and Dudík (2008). MaxEnt models were trained using $75 \%$ of the sample point data and tested against the remainder. Model performance was assessed using the Akaike information criterion $\left(\mathrm{AIC}_{\mathrm{c}}\right)$ as it has been shown to outperform BIC and AUC based methods (Warren and Seifert 2011). Model selection was succeeded using ENMTools package (Warren et al. 2010).

\section{Place prioritization}

Occurrence probability maps derived from MaxEnt models were analyzed using Zonation software (v2.0) (Moilanen et al. 2005; Moilanen 2007) to identify the high value areas of Crete. Zonation is a site prioritization method (Moilanen et al. 2005) that produces a hierarchical prioritization of a landscape, based on the biological value of sites (cells). The algorithm uses the complementarity principle together with connectivity, and as a result, landscapes can be zoned according to their conservation potential. This is done by iteratively removing cells whose loss will cause the smallest decrease in the conservation value of the remaining network. The removal rule used was the core-area Zonation, because the primary aim of the analysis was to ensure the conservation of the total orchid flora in the study area (Moilanen et al. 2005). In core-area Zonation, cell removal is done by picking cell $\mathrm{i}$ that has the smallest value (minimizing biological loss) for the most valuable occurrence over all species in the cell.

A species weighting scheme has been applied using the Species Specialization Index formula, as described by Tsiftsis et al. (2009). Species weight reflects the relative importance of a species in comparison to other species, while Species Specialization Index reflects species' niche breadth. The latter was calculated using "Measuring niche breadth" function of the ENMTools package (Warren et al. 2010).

The relationship between site scoring, calculated by the Zonation analysis, and specific environmental variables was investigated using regression tree analysis (Breiman et al. 1984; De'ath and Fabricius 2000). The variables used in the regression tree analysis were altitude, longitude, latitude, heat load index (HLI), Euclidean distance of each grid cell from the nearest coast, geological substrate, and vegetation type. Regression tree models can uncover complex interactions between independent variables (species attributes), providing a hierarchical method of splitting a data set into smaller homogeneous groups in which the within-group variation in the response variable is minimized. At each node of the tree, species are divided into two groups based on a certain value of a selected attribute (splitter independent variable). In selecting the optimal tree size, the 10-fold cross-validation method with the SE rule = 1 was used. The cross-validation procedure gives an estimate of the pruning level needed to select (automatically) a particular tree that appears most stable and valid. Explained variation of the best tree produced by the regression tree analysis was calculated from the resubstitution relative error, which corresponds to the residual sum of squares. Explanatory variables used in the model contribute to a different extent to the explained variation in the dependent variable. The influence of explanatory variables was evaluated by the relative importance values.

\section{Results}

After omitting the variables with a high intercorrelation $(r>0.75)$, those remaining to be included in the MaxEnt software were annual mean temperature (BIO1), isothermality (BIO3), annual precipitation (BIO12), precipitation seasonality (BIO15), heat load index (HLI), geological substrate and vegetation type.

Variable importance and species specialization index, based on species' niche breadth, are shown on Table 1 . The most important variables, defined by the MaxEnt model, were the geological substrate (mean \pm SD: $27 \%$ \pm 19.03 ), the annual precipitation (mean \pm SD: $16.92 \%$ \pm 14.67 ) and the annual mean temperature (mean \pm SD: 
Table 1 Heuristic estimate of relative contributions of the variables (\%) included into the analysis (Bio1: annual mean temperature; Bio3 isothermality; Bio12: annual precipitation; Bio15: precipitation seasonality; Geol.: geological substrate; Veg.: vegetation type; HLI: Heat Load Index; Occ: number of records; SSI: species specialization index).

\begin{tabular}{|c|c|c|c|c|c|c|c|c|c|}
\hline & BIO1 & $\mathrm{BIO3}$ & B1012 & BIO15 & GEOL & VEG & HLI & Occ & SSI \\
\hline Anacamptis boryi & 6.1 & 14.4 & 47.5 & 14.3 & 8.5 & 6.9 & 2.3 & 107 & 0.429 \\
\hline Anacamptis collina & 13.5 & 4.3 & 17.1 & 10.7 & 41.2 & 11.2 & 2.0 & 564 & 0.132 \\
\hline Anacamptis coriophora subsp. fragrans & 16.8 & 1.6 & 10.0 & 5.0 & 49.7 & 12.0 & 4.9 & 363 & 0.102 \\
\hline Anacamptis laxiflora & 2.9 & 7.5 & 36.6 & 15.6 & 23.2 & 10.6 & 3.6 & 199 & 0.320 \\
\hline Anacamptis papilionacea subsp. papilionacea & 4.9 & 9.4 & 24.9 & 4.9 & 28.1 & 24.4 & 3.4 & 107 & 0.244 \\
\hline Anacamptis papilionacea subsp. alibertis & 0.2 & 0.0 & 18.1 & 0.3 & 70.1 & 11.1 & 0.2 & 9 & 0.545 \\
\hline Anacamptis papilionacea subsp. heroica & 15.2 & 20.6 & 7.3 & 10.3 & 32.5 & 12.7 & 1.4 & 653 & 0.098 \\
\hline Anacamptis pyramidalis & 20.4 & 1.7 & 13.5 & 37.1 & 11.1 & 13.7 & 2.5 & 538 & 0.081 \\
\hline Anacamptis sancta & 9.8 & 74.3 & 0.0 & 0.0 & 4.6 & 9.2 & 2.1 & 12 & 0.530 \\
\hline Cephalanthera cucullata & 58.2 & 1.1 & 19.8 & 1.1 & 4.4 & 11.4 & 4.0 & 26 & 0.767 \\
\hline Cephalanthera damasonium & 9.5 & 0.0 & 77.9 & 0.0 & 4.8 & 7.8 & 0.0 & 7 & 0.911 \\
\hline Cephalanthera longifolia & 18.8 & 24.7 & 0.0 & 0.0 & 43.3 & 13.2 & 0.0 & 17 & 0.698 \\
\hline Dactylorhiza romana & 5.1 & 5.7 & 20.9 & 1.4 & 52.0 & 11.1 & 3.8 & 47 & 0.439 \\
\hline Epipactis cretica & 77.4 & 0.1 & 2.9 & 6.6 & 4.7 & 3.9 & 4.4 & 24 & 0.631 \\
\hline Epipactis microphylla & 0.0 & 12.8 & 0.0 & 0.0 & 22.5 & 64.7 & 0.0 & 17 & 0.349 \\
\hline Himantoglossum robertianum & 1.1 & 5.2 & 16.6 & 21.1 & 39.5 & 14.9 & 1.6 & 510 & 0.138 \\
\hline Himantoglossum samariense & 51.1 & 3.0 & 1.4 & 0.6 & 23.9 & 17.2 & 2.8 & 21 & 0.744 \\
\hline Limodorum abortivum & 15.1 & 2.1 & 6.8 & 18.7 & 12.6 & 36.8 & 7.9 & 86 & 0.167 \\
\hline Neotinea lactea & 14.1 & 9.1 & 39.1 & 4.9 & 23.3 & 8.3 & 1.2 & 370 & 0.235 \\
\hline Neotinea maculata & 27.4 & 6.9 & 19.1 & 13.4 & 12.1 & 9.7 & 11.4 & 129 & 0.183 \\
\hline Neotinea tridentata & 51.3 & 1.7 & 33 & 0.2 & 4.4 & 4.3 & 5.1 & 54 & 0.422 \\
\hline Neottia ovata & 1.1 & 10.3 & 1.4 & 0.0 & 65.5 & 17.1 & 4.6 & 20 & 0.692 \\
\hline Ophrys apifera & 0.7 & 15.6 & 7.2 & 6.9 & 30.8 & 20.7 & 18.1 & 74 & 0.117 \\
\hline Ophrys bilunulata & 3.0 & 2.3 & 44.2 & 3.9 & 22.6 & 0.3 & 23.7 & 21 & 0.499 \\
\hline Ophrys bombyliflora & 21.4 & 15.4 & 10.9 & 7.9 & 33.2 & 9.9 & 1.3 & 456 & 0.138 \\
\hline Ophrys candica & 1.3 & 23.4 & 21.8 & 8.4 & 29.1 & 9.5 & 6.5 & 115 & 0.302 \\
\hline Ophrys cretica subsp. ariadnae & 11.2 & 15.8 & 13.8 & 6.9 & 38.5 & 10.2 & 3.6 & 486 & 0.205 \\
\hline Ophrys cretica subsp. cretica & 10.0 & 12.0 & 23.2 & 8.2 & 28.7 & 14 & 3.9 & 180 & 0.213 \\
\hline Ophrys episcopalis & 6.2 & 19.4 & 26.9 & 16.2 & 16.3 & 11.4 & 3.6 & 381 & 0.082 \\
\hline Ophrys fleischmannii & 12.3 & 8.0 & 3.9 & 47.9 & 5.9 & 14.6 & 7.4 & 79 & 0.365 \\
\hline Ophrys fusca subsp. cinereophila & 10.5 & 2.0 & 15.4 & 18.1 & 32.9 & 12.2 & 8.9 & 208 & 0.213 \\
\hline Ophrys fusca subsp. creberrima & 15.9 & 10.8 & 38.4 & 1.4 & 26.3 & 5.8 & 1.4 & 76 & 0.250 \\
\hline Ophrys fusca subsp. cressa & 37.0 & 12.3 & 0.9 & 15.0 & 10.6 & 13.8 & 10.4 & 31 & 0.483 \\
\hline Ophrys fusca subsp. creticola & 5.4 & 14.9 & 28.0 & 0.0 & 27.9 & 17.2 & 6.6 & 20 & 0.296 \\
\hline Ophrys fusca subsp. funerea & 1.0 & 11.8 & 24.2 & 0.6 & 41.3 & 14.6 & 6.5 & 32 & 0.334 \\
\hline Ophrys fusca subsp. thriptiensis & 30.9 & 11.0 & 0.0 & 36.8 & 13.4 & 7.9 & 0.0 & 10 & 0.751 \\
\hline Ophrys grammica & 11.3 & 6.5 & 6.6 & 14.3 & 35.4 & 13.7 & 12.2 & 219 & 0.123 \\
\hline Ophrys heldreichii & 21.9 & 10.3 & 24.5 & 9.1 & 21.1 & 12.4 & 0.7 & 597 & 0.105 \\
\hline Ophrys iricolor subsp. iricolor & 4.5 & 11.9 & 18.6 & 17.8 & 35.4 & 10.5 & 1.3 & 409 & 0.167 \\
\hline Ophrys iricolor subsp. mesaritica & 0.1 & 0.1 & 0.0 & 0.0 & 83.8 & 15.8 & 0.2 & 17 & 0.453 \\
\hline Ophrys lutea subsp. melena & 28.5 & 45.6 & 12.5 & 7.4 & 2.4 & 3.0 & 0.6 & 8 & 0.168 \\
\hline Ophrys lutea subsp. minor & 10.0 & 9.6 & 18.3 & 20.8 & 27.1 & 10.4 & 3.8 & 759 & 0.095 \\
\hline Ophrys lutea subsp. phryganae & 9.4 & 14.3 & 7.5 & 32.3 & 15.9 & 18.3 & 2.3 & 504 & 0.067 \\
\hline Ophrys mammosa & 14.0 & 19.2 & 3.3 & 7.4 & 24.9 & 27.1 & 4.1 & 292 & 0.114 \\
\hline Ophrys omegaifera subsp. basilissa & 3.1 & 21.6 & 4.6 & 1.6 & 54.4 & 12.2 & 2.5 & 84 & 0.388 \\
\hline
\end{tabular}




\begin{tabular}{|c|c|c|c|c|c|c|c|c|c|}
\hline & BIO1 & $\mathrm{BIO3}$ & BIO12 & BI015 & GEOL & VEG & HLI & Occ & SSI \\
\hline Ophrys omegaifera subsp. omegaifera & 4.2 & 25.7 & 5.2 & 38.5 & 9.9 & 10.6 & 5.9 & 322 & 0.219 \\
\hline Ophrys sitiaca & 1.9 & 27.3 & 3.1 & 24.5 & 12.8 & 28.6 & 1.8 & 40 & 0.377 \\
\hline Ophrys speculum & 3.2 & 2.0 & 5.0 & 2.0 & 83.8 & 2.8 & 1.2 & 8 & 0.0 \\
\hline Ophrys sphegodes subsp. cretensis & 26.3 & 1.8 & 16.5 & 23.1 & 8.7 & 21.6 & 2.0 & 432 & 0.128 \\
\hline Ophrys sphegodes subsp. gortynia & 9.7 & 11.0 & 5.2 & 1.1 & 66.1 & 3.3 & 3.6 & 89 & 0.344 \\
\hline Ophrys spruneri subsp. grigoriana & 6.7 & 34.3 & 4.9 & 0.0 & 37.1 & 8.3 & 8.7 & 26 & 0.322 \\
\hline Ophrys spruneri subsp. spruneri & 4.1 & 19.8 & 29.6 & 2.1 & 29.8 & 9.6 & 5.0 & 153 & 0.213 \\
\hline Ophrys tenthredinifera & 13.9 & 5.4 & 23.7 & 12.1 & 34.8 & 6.2 & 3.9 & 502 & 0.128 \\
\hline Orchis anatolica & 31.5 & 20.7 & 5.1 & 34.5 & 1.2 & 5.2 & 1.8 & 212 & 0.436 \\
\hline Orchis anthropophora & 19.7 & 11.1 & 31.3 & 18.8 & 7.6 & 7.4 & 4.1 & 162 & 0.229 \\
\hline Orchis italica & 13.6 & 6.5 & 23.9 & 14.0 & 27.3 & 14.1 & 0.6 & 683 & 0.094 \\
\hline Orchis pauciflora & 40.9 & 6.2 & 34.0 & 6.3 & 7.1 & 4.6 & 0.9 & 266 & 0.409 \\
\hline Orchis prisca & 48.4 & 7.9 & 7.1 & 10.3 & 10.0 & 8.5 & 7.8 & 44 & 0.576 \\
\hline Orchis provincialis & 29.1 & 4.5 & 1.6 & 0.0 & 40.9 & 5.3 & 18.6 & 22 & 0.537 \\
\hline Orchis quadripunctata & 23.2 & 0.8 & 44.2 & 15.3 & 10.3 & 3.5 & 2.7 & 501 & 0.157 \\
\hline Orchis simia & 1.8 & 29.9 & 13.8 & 24.4 & 21.1 & 6.8 & 2.2 & 118 & 0.311 \\
\hline Orchis sitiaca & 43.2 & 12.0 & 8.3 & 9.7 & 15.1 & 9.5 & 2.2 & 104 & 0.486 \\
\hline Serapias bergonii & 22.5 & 0.5 & 19.7 & 14.7 & 34.1 & 7.4 & 1.1 & 680 & 0.112 \\
\hline Serapias cordigera subsp. cretica & 3.8 & 0.7 & 18.1 & 2.7 & 45.5 & 17.0 & 12.2 & 54 & 0.166 \\
\hline Serapias lingua & 17.3 & 23.8 & 35.2 & 4.3 & 6.2 & 9.7 & 3.5 & 224 & 0.291 \\
\hline Serapias orientalis & 9.5 & 7.8 & 21.1 & 8.6 & 38.7 & 12.1 & 2.2 & 366 & 0.156 \\
\hline Serapias parviflora & 3.4 & 4.7 & 23.6 & 17.8 & 30.1 & 15.4 & 5.0 & 156 & 0.209 \\
\hline Spiranthes spiralis & 0.0 & 0.0 & 1.6 & 0.2 & 18.1 & 40.2 & 39.9 & 10 & 0.238 \\
\hline Mean & 15.7 & 11.67 & 16.92 & 10.88 & 27.0 & 12.87 & 4.94 & 207.4 & 0.315 \\
\hline SD & 15.95 & 12.08 & 14.67 & 11.11 & 19.03 & 9.61 & 6.24 & 213.7 & 0.217 \\
\hline
\end{tabular}

$15.70 \% \pm 15.95)$. In contrast, the least important variable was the heat load index (mean \pm SD: $4.94 \% \pm 6.24$ ). Based on the species specialization index (SSI), the most specialist orchids were found to be the Cephalanthera damasonium (0.91), C. cucullata (0.77), O. fusca subsp. thriptiensis (0.75), Himantoglossum samariense (0.74), Cephalanthera longifolia (0.70), Neottia ovata (0.69) and Epipactis cretica (0.63) (Table 1). In contrast, the more generalist species were Ophrys speculum (0.0), Ophrys lutea subsp. phryganae (0.07), Anacamptis pyramidalis (0.08), Ophrys episcopalis (0.08) and Ophrys lutea subsp. minor (0.09).

Based on the results from the Zonation analysis, the most important areas for orchid conservation were located on Mts Thripti, Ida and Lefka Ori, as well as east of Heraklion and the easternmost part of the island (Fig. 1). The altitudes of the high value areas vary greatly (Fig. 2). However, Pearson correlation coefficient calculated between grid cell ranking score and altitude has shown a significantly positive relationship $(\mathrm{r}=0.51 ; \mathrm{P}<0.001)$. A large proportion of the grid cells located in the low altitude areas of the island could be characterized as nonsignificant for orchid conservation, while on the contrary, the high-altitude areas of the island are characterized by high scores reflecting their importance (Fig. 2).
The optimal regression tree was divided into 16 terminal nodes and explained $36.55 \%$ of the variation in the data set (Fig. 3). In the first node, the data set was divided into two main groups according to their elevation with grid cells of highest scores occurring above $542.5 \mathrm{~m}$. In the second node the division has been performed according to the geological substrate, while in the third one, latitude has been selected as the division variable. More specifically, grid cells with the highest ranking $(\mathrm{M}=0.834 ; \mathrm{n}=238)$ were those with altitude ranging between 542.5 and $969.5 \mathrm{~m}$, occurring in all the geological substrates of Crete except those of schist, gneiss, flysch and phyllites and located eastern of Thripti. The node representing grid cells with the second highest mean $\operatorname{rank}(\mathrm{M}=0.791 ; \mathrm{n}=1480)$ was characterized by those grid cells at an altitude above $969.5 \mathrm{~m}$, distributed all over Crete. High ranking grid cells $(M=0.781 ; n=789)$ have also been recorded in the mid-altitude areas (those occurring between 542.5 and $969.5 \mathrm{~m}$ ) of Crete having schist, gneiss, flysch and phyllites as geological substrate. Furthermore, low-altitude areas $(266.5<$ Alt $\leq 542.5 \mathrm{~m})$ on schist, gneiss, flysch, phyllites, diabases, ophiolites and belonging to the counties of Chania and Lassithi are also characterized by relative high grid cell ranking $(\mathrm{M}=0.684 ; \mathrm{n}=778)$. On the other hand, grid cells with 




Fig. 1 Results of Zonation analysis and the current Natura 2000 network of protected areas in Crete.

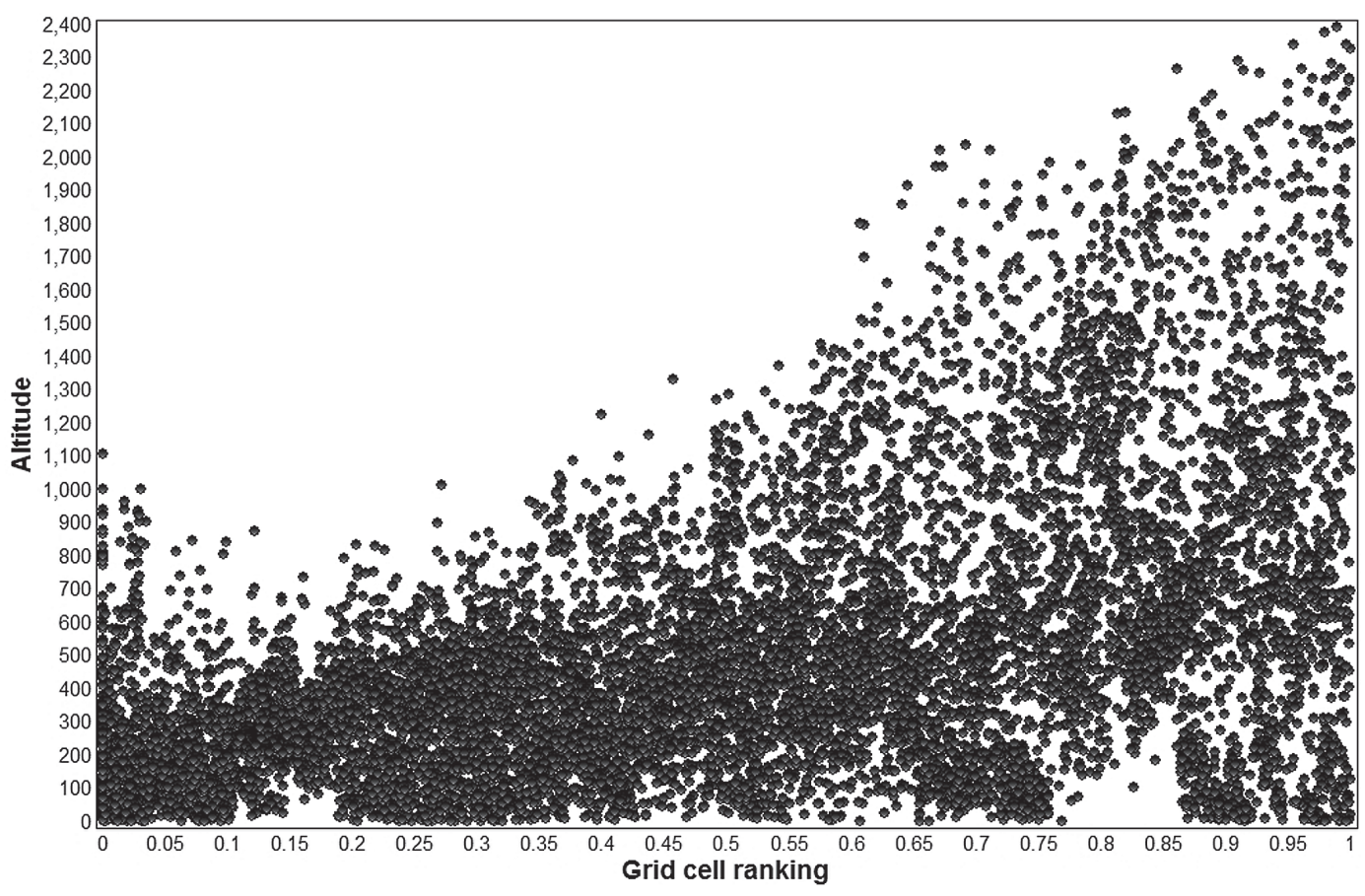

Fig. 2 Relationship between altitude and grid cell ranking.

the lowest ranking $(\mathrm{M}=0.118 ; \mathrm{n}=764)$ were located on the north-central and north-western part of the island, in low altitude areas, with deposits as the geological substrate.

Most of the variation in the grid cells' ranking was explained by geological substrate (variable rank: 100), latitude (81) and altitude (77) followed by longitude (71). On the contrary, vegetation type has been identified as the least important variable (variable rank: 34 ) and together with the heat load index and the Euclidean distance of each grid cell from the nearest coast, has not been used in splitting the regression tree into nodes.

\section{Discussion}

Identifying areas of high importance is essential for the conservation of biodiversity (Hunter and Gibbs 2007). Although, until recently, existing knowledge of species distribution was used to identify hotspots of biodiversity or other important areas (Williams et al. 1996; Dimitrakopoulos et al. 2004; Sólymos and Fehér 2005), nowadays, novel techniques, such as niche modelling and reserve selection methods are usually combined to set conservation priorities (Pawar et al. 2007; Kremen et al. 2008; Girardello et al. 2009). 


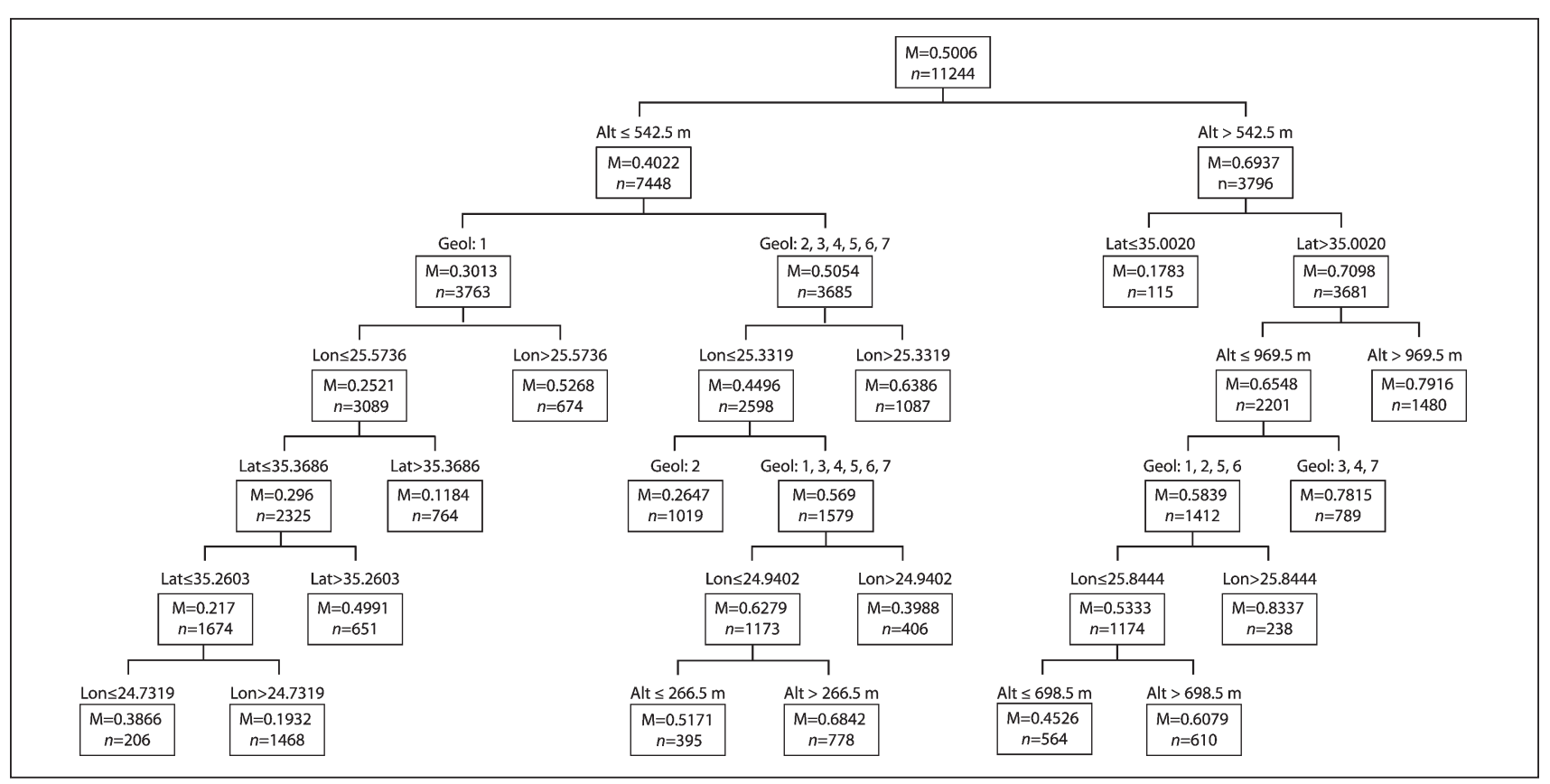

Fig. 3 Regression tree explaining grid cell ranking. In each node, the splitter variable with its split value, the mean rank of grid cells (M) and number of cells $(n)$ assigned to that node are given. Abbreviations of the geological substrate types used in the regression tree analysis: $1=$ deposits; 2 = limestone; $3=$ schist and gneiss; 4 = flysch; $5=$ diabases $6=$ ophiolite; $7=$ phyllites .

The important areas for orchid conservation in Crete, as determined from the present study, are partly congruent with those identified by Kretzschmar et al. (2002). The latter were based on the actual records of orchids and on the estimation of orchid species richness. According to Kretzschmar et al. (2002), the orchid-rich areas, and thus of high conservation value, are located on Mt Thripti, the southwestern slopes of Mt Ida, east of Mt Dikti and to a lesser extent on Mt Lefka Ori. Our results indicate two additional important areas for orchid conservation; these are located east of Heraklion, and near Agios Nikolaos. These areas are at low altitude, in contrast to the other important areas, as identified in this study and by Kretzschmar et al. (2002).

Although these two areas do not have high species richness, they have been classified as highly important due to the high probability of occurrence for the rare orchid Anacamptis sancta. This species is widely distributed in the Cyclades and the eastern Aegean islands, but is especially rare on Crete. The difference between our results and those of Kretzschmar et al. (2002) could be attributed to the fact that the latter are based on species richness, while the former on the basic core-area cell removal rule of the Zonation algorithm that ranks grid cells according to the probabilities of occurrence of species in each cell, while species richness comes second in their ranking procedure. Consequently, otherwise species-poor cells can be highly ranked if there is a very high probability of occurrence for a single rare species (Moilanen et al. 2005; Moilanen 2007), making these cells more adequate for the conservation of rare species. Furthermore, grid cell ranking is strongly influenced from the weight scheme applied in the selection algorithm (Moilanen et al. 2005; Moilanen 2007). The fact that in the present analysis the species specialization index (SSI) was used as a weighting scheme, forced the Zonation algorithm to rank grid cells where specialist species such as C. cucullata, E. cretica, C. damasonium, N. ovata and O. fusca subsp. thriptiensis occur more highly.

Orchid distribution determined using MaxEnt did not differ significantly from the distribution maps provided by Kretzschmar et al. (2002). This high congruence between recorded and modelled species distribution could be attributed to the extensive field recording made in the past, which resulted in a detailed mapping of orchid distribution. However, even in this case, distribution models from MaxEnt revealed new species localities, indicating a possible bias of field sampling towards more accessible areas. Another difference between modelled and recorded distribution concerns the fact that MaxEnt detected relatively low probabilities of orchids' occurrences for the areas where species records were relatively far from their main distribution and possibly represent vagrant occurrences.

The application of regression trees aimed at the identification of the factors affecting the conservation value of an area. Geological substrate was found as the most important factor that determined the conservation value. This is in accordance with the results of previous studies (Dijk et al. 1997; Tsiftsis et al. 2008), which indicated the significance of soil properties in determining orchid distribution. In fact, geological substrate is a surrogate of soil properties. High conservation value areas in Crete were found to occur mostly on limestone and deposits 
(mainly derived from calcareous rocks) which both form soils with relatively high $\mathrm{pH}$ values that usually host a rich orchid flora (Davies et al. 1984).

Furthermore, the positive correlation between grid cell ranking and altitude indicates that high value grid cells are mainly located in medium and high altitudes. However, Cretan orchids do not always present higher probabilities of occurrence at high altitudes. The calculation of Pearson correlation coefficient between probability of occurrence and ecological variables such as annual precipitation and annual mean temperature showed that some species (e.g. Ophrys mammosa, Anacamptis coriophora subsp. fragrans, Serapias bergonii, Ophrys bombyliflora, Anacamptis papilionacea subsp. heroica, Serapias orientalis) were highly positively correlated with the mean annual temperature, while some other orchid species, such as E. cretica, C. cucullata, $H$. samariense, Orchis prisca, Neotinea tridentata and $C$. damasonium, were highly negatively correlated. In addition, the latter orchids have also been found to prefer habitats with high annual precipitation. As both the above-mentioned variables are highly correlated with altitude ( -0.96 and 0.69 , respectively) it is concluded that some orchids shown a niche specialization according to the latter factor. The higher conservation values at higher altitudes may be due to the higher rarity and specialization index of the species restricted to these altitudes.

The addition of geographical coordinates in the regression tree model actually restricts the high conservation value areas to Mts Ida, Thripti and Lefka Ori, which are the main hotspots for orchid diversity according to our results and those of Kretzschmar et al. (2002). Regression tree analysis, therefore, indicates that both ecological and spatial factors determine the high conservation value areas for orchids in Crete.

Surprisingly, vegetation type was not included in the regression tree model, although it is known to be closely related with the distribution of orchids (Tsiftsis et al. 2008; Landi et al. 2009). This can be attributed to the resolution of the vegetation data (grid cells of $1 \mathrm{~km}^{2}$ ), which despite being adequate for conservation planning, it seems that it cannot ascribe the small scale differentiation of vegetation. Some orchids are restricted to certain microhabitats, which represent a narrow range of biotic and abiotic conditions (Kretzschmar et al. 2002; Delforge 2006). Thus, there is need to conserve a range of microhabitats in addition to a greater reserve network. The current Natura 2000 network sites on Crete cover 32\% of the total area of the island $\left(2778 \mathrm{~km}^{2}\right)$, which is very high in comparison with that usually devoted for conservation purposes (Hunter and Gibbs 2007). However, this large conservation network is only partly congruent with the important areas identified in the present study (Fig. 1). This is possibly due to only one of the Cretan orchid species (C. cucullata) being included in the annex of the species of Community Priority of the Habitats Directive (92/43/EEC; Dafis et al. 1996), while the habitats of Community Interest are more generally defined and thus cannot represent the microhabitats that host rare and endangered orchid species. In several countries, microreserves (Laguna 2001) have been recently established within protected areas to direct conservation actions to very rare and stenotopic species. In Greece, a pilot network of plant micro-reserves has already been established in western Crete focusing on the effective conservation of six plant species of Community Priority and the Phoenix palm groves (Thanos et al. 2005). Among the seven micro-reserves that have been established, one was set up for monitoring and conservation of the orchid C. cucullata. However, the results of the present study indicate that a network of micro-reserves should also be established both within and outside the Natura 2000 network on Crete, to focus on the conservation of microhabitats that support rare and threatened orchid taxa. According to our results, other species eligible for targeted habitat conservation are E. cretica, $H$. samariense, O. bilunulata and O. prisca.

Aside from C. cucullata and E. cretica which have been included in the Red Data Book of Rare and Threatened Plants of Greece (Alibertis and Avramakis 2009a,b), there are a number of orchid species in need of targeted conservation. C. damasonium and $N$. ovata are not rare in Greece, but they have a restricted distribution on Crete (Kretzschmar et al. 2002) and are endangered by overgrazing. As mentioned by Hill et al. (1998), Crete represents a characteristic case of land degradation resulting from hundreds of years of intensive grazing. However, both absence of grazing animals and overgrazing could cause the decrease of orchid populations, due to vegetation encroachment or an increase in soil compaction. O. fusca subsp. thriptiensis is an endemic species restricted to the calcareous areas of Mt Thripti (Delforge 2006) and should also be prioritized for conservation. Areas in which this orchid grows were also highly ranked according to the Zonation analysis (Fig. 1). In addition, A. palustris subsp. elegans should also be protected due to this species occupying low altitude coastal areas (Kretzschmar et al. 2002), where it is threatened by urbanization and increased tourism.

Among the main threats that Mediterranean orchids face today, Stewart (1992) determined urbanization, changes in land use, increasing use of fertilizers, herbicides and insecticides, and the increasing grazing pressure, most of which stand for the Cretan orchids. Effective conservation measures should involve (a) the identification of high value areas, (b) the determination of factors that are highly correlated with the spatial distribution of these areas, and (c) increased knowledge of species ecology (Stewart 1992; Hágsater and Dumont 1996; Tsiftsis et al. 2008). The present study deals mainly with the first two issues, and highlights the taxa and areas where ecological data (e.g. population dynamics) should be collected and monitoring schemes established to ensure the persistence of rare species and overall orchid diversity on Crete. 


\section{Acknowledgements}

We would like to thank Horst Kretzschmar, Hans Rauschenberger, Uwe Grabner, Anita Allsopp, Zissis Antonopoulos, Karel Kreutz, Maria Petrou and Antonis Alibertis for providing unpublished data or information about the distribution of the orchids of Crete, and two anonymous reviewers for their valuable comments and suggestions.

\section{REFERENCES}

Alibertis A, Avramakis M (2009a) Cephalanthera cucullata Boiss. and Heldr. In: Phitos D, Constantinidis T, Kamari G (eds) The Red Data Book of Rare and Threatened Plants of Greece, Vol. I (A-D). Hellenic Botanic Society, Patra, pp 258-260.

Alibertis A, Avramakis M (2009b) Epipactis cretica Kalop. and Robatsch. In: Phitos D, Constantinidis T, Kamari G (eds) The Red Data Book of Rare and Threatened Plants of Greece, Vol. II (E-Z). Hellenic Botanic Society, Patra, pp 12-13.

Anderson RP, Lew D, Peterson AT (2003) Evaluating predictive models of species' distributions: criteria for selecting optimal models. Ecol Model 162: 211-232.

Anon (2008) ArcGIS - ArcMap: ArcInfo (version 9.3). Environmental Science Research Institute (ESRI) Inc. Redlands, CA, US.

Ardron JA, Possingham HP, Klein CJ (eds) (2008) Marxan Good Practices Handbook. External review version; 17 May, 2008. Pacific Marine Analysis and Research Association, Vancouver, BC, Canada, www.pacmara.org.

Barbero M, Quézel P (1980) La vegétation forestière de Crète. Ecol Mediter 5: 175-210.

Bateman RM, Pridgeon AM, Chase MW (1997) Phylogenetics of subtribe Orchidinae (Orchidoideae, Orchidaceae) based on nuclear ITS sequences. 2. Infrageneric relationships and reclassification to achieve monophyly of Orchis sensu stricto. Lindleyana 12(3): 113-141.

Breiman L, Friedman JH, Olshen RA, Stone CG (1984) Classification and regression trees. Wadsworth International Group, Belmont.

Chase MW, Cameron KM, Barrett RL, Freudebstein JV (2003) DNA data and Orchidaceae systematics: a new phylogenetic classification. In: Dixon KW, Kell SP, Barrett RL, Cribb PJ (eds) Orchid conservation. Natural History Publications, Kota Kinabalu, Sabah, pp 69-89.

Dafis S, Papastergiadou E, Georghiou K, Babalonas D, Georgiadis T, Papageorgiou M, Lazaridou T, Tsiaoussi V (1996) Directive 92/43. EEC The Greek "Habitat" Project NATURA 2000: an Overview. The Goulandris Natural History Museum, Greek Biotope-Wetland Centre, Thessaloniki.

Davies P, Davies J, Huxley A (1984) Wild orchids of Britain and Europe. 2nd ed, Chatto and Windus-The Hogarth Press, London.

De'ath G, Fabricius KE (2000) Classification and regression trees: a powerful yet simple technique for ecological data analysis. Ecology 81: 3178-3192.

Delforge P (2006) Orchids of Europe, North Africa and the Middle East. 3rd edition, A and C Black Publishers Ltd., London.

Dijk E, Willems JH, van Andel J (1997) Nutrient responses as a key factor to the ecology of orchid species. Acta Bot Neerl 46: 339-363.

Dimitrakopoulos PG, Memtsas D, Troumbis AY (2004) Question- ing the effectiveness of the Natura 2000 special areas of conservation strategy: the case of Crete. Global Ecol Biogeogr 13: 199-207.

Dimopoulos P, Sykora KV, Mucina L, Georgiadis T (1997) The high rank syntax of the rock cliff and scree vegetation of the mainland Greece and Crete. Folia Geobot 32: 313-334.

Elith J, Graham CH, Anderson RP, Dudik M, Ferrier S, Guisan A, Hijmans RJ, Huettmann F, Leathwick JR, Lehmann A, Li J, Lohmann LG, Loiselle BA, Manion G, Moritz C, Nakamura M, Nakazawa Y, Overton JM, Peterson AT, Phillips SJ, Richardson K, Scachetti-Pereira R, Schapire RE, Soberon J, Williams S, Wisz MS, Zimmermann NE (2006) Novel methods improve prediction of species' distributions from occurrence data. Ecography 29: 129-151.

Elith J, Leathwick J (2009) The contribution of species distribution modelling to conservation prioritization. In: Moilanen A, Wilson AK, Possingham HP (eds) Spatial conservation prioritization. Quantitative methods and computational tools. Oxford University Press Inc., New York, pp 70-93.

Ferrier S, Faith DP, Arponen A, Drielsma M (2009) Communitylevel approaches to spatial conservation prioritization. In: Moilanen A, Wilson AK, Possingham HP (eds) Spatial conservation prioritization. Quantitative methods and computational tools. Oxford University Press Inc., New York, pp 94-109.

Ferrier S, Guisan A (2006) Spatial modelling of biodiversity at the community level. J Appl Ecol 43: 393-404.

Ferrier S, Wintle BA (2009) Quantitative approaches to spatial conservation prioritization: matching the solution to the need. In: Moilanen A, Wilson AK, Possingham HP (eds) Spatial conservation prioritization. Quantitative methods and computational tools. Oxford University Press Inc., New York, pp 1-15.

Fleischmann H (1925) Beitrag zur Orchideenflora der insel Kreta. Oesterr Bot Z 74(7-9): 180-194.

Game ET, Grantham HS (2008) Marxan User Manual: For Marxan version 1.8.10. University of Queensland, St. Lucia, Queensland, Australia, and Pacific Marine Analysis and Research Association, Vancouver, British Columbia, Canada.

Garson J, Aggarwal A, Sarkar S (2002) ResNet Manual, ver. 1.2. University of Texas at Austin, Austin.

Gelfand AE, Schmidt AM, Wu S, Silander JA, Latimer A, Rebelo AG (2005) Modelling species diversity through species level hierarchical modelling. Appl Statist 54: 1-20.

Girardello M, Griggio M, Whittingham MJ, Rushton SP (2009) Identifying important areas for butterfly conservation in Italy. Anim Conserv 12: 20-28.

Guisan A, Edwards TC, Hastie T (2002) Generalized linear and generalized additive models in studies of species distributions: setting and scene. Ecol Model 157: 89-100.

Hágsater E, Dumont V (eds) (1996) Orchids: status, survey and conservation action plan. IUCN, Gland, Switzerland and Cambridge, UK.

Hijmans RJ, Cameron SE, Parra JL, Jones PG, Jarvis A (2005) Very high resolution interpolated climate surfaces for global land areas. Int J Climatol 25: 1965-1978.

Hill J, Hostert P, Tsiourlis G, Kasapidis P, Udelhoven T, Diemer C (1998) Monitoring 20 of increased grazing impact on the Greek island of Crete with earth observation satellites. J Arid Environ 39: $165-178$.

Hunter ML, Cibbs J (2007) Fundamentals of conservation biology. 3rd edition, Blackwell Publishing Ltd.

Hutchings MJ (1989) Population biology and conservation of Ophrys sphegodes. In: Pritchard HW (ed) Modern methods in orchid conservation: the role of physiology, ecology and management. Cambridge University Press, Cambridge, pp 101-115. 
IGME (1983) Geological map of Greece, 1 : 500,000. IGME, Athens.

Kalopissis J, Robatsch K (1980) Epipactis cretica Kalopissis et Robatsch spec. nov., ein neuer kretischer Endemit. Die Orchidee 31(4): 141-143.

Kremen C, Cameron A, Moilanen A, Phillips SJ, Thomas CD, Beentje H, Dransfield J, Fisher BL, Glaw F, Good TC, Harper GJ, Hijmans RJ, Lees DC, Louis Jr, E, Nussbaum RA, Raxworthy CJ, Razafimpahanana A, Schatz GE, Vences M, Vieites DR, Wright PC, Zjhra ML (2008) Aligning conservation priorities across taxa in Madagascar with high-resolution planning tools. Science 320: 222-226.

Kretzschmar H, Kretzschmar G, Eccarius W (2002) Orchideen auf Kreta, Kasos, Karpathos. Selbstverlag H Kretzschmar, Bad Hersfeld.

Kreutz CAJ (1990) Beitrag zur Orchideenflora Kretas. Mitt Bl Arbeitskr Heim Orch Baden-Württ 22(2): 358-384.

Kreutz CAJ (2004) Kompendium der Europaischen Orchideen. Kreutz Publishers, Landgraaf.

Kull T, Kindlmann P, Hutchings M, Primack B (2006) Conservation biology of orchids: Introduction to the special issue. Biol Conserv 129: 1-3.

Laguna E (2001) The micro-reserves as a tool for conservation of threatened plants in Europe. Nature and environment, No. 121. Council of Europe, Strasbourg.

Landi M, Frignani F, Lazzeri C, Angiolini C (2009) Abundance of Orchids on Calcareous Grasslands in Relation to Community Species, Environmental, and Vegetational Conditions. Russian J Ecol 40: 486-494.

Loiselle BA, Howell CA, Graham CH, Goerck JM, Brooks T, Smith KG, Williams PH (2003) Avoiding pitfalls of using species distribution models in conservation planning. Conserv Biol 17: 1591-1600.

Manuel RL (1996) Orchidées de Crète - Une compilation de mentions récentes. Natural Belges 77(Orchid. 9): 137-170.

Margules CR, Pressey RL (2000) Systematic conservation planning. Nature 450: 243-253.

McCune B, Keon D (2002) Equations for potential annual direct incident radiation and heat load. J Veg Sci 13: 603-606.

Moilanen A (2007) Landscape zonation, benefit functions and target-based planning: unifying reserve selection strategies. Biol Conserv 134: 571-579.

Moilanen A, Franco AMA, Early RI, Fox R, Wintle B, Thomas CD (2005) Prioritizing multiple-use landscapes for conservation: methods for large multi-species planning problems. Proc R Soc Lond Ser B - Biol Sci 272: 1885-1891.

Mountrakis D (1985) Geology of Greece. Thessaloniki (In Greek).

Neitlich P, McCune B (1997) Hotspots of Epiphytic Lichen diversity in two young managed forests. Conserv Biol 11: 172-182.

Pawar S, Koo MS, Kelley C, Ahmed MF, Chaudhuri S, Sarkar S (2007) Conservation assessment and prioritization of areas in Northeast India: Priorities for amphibians and reptiles. Biol Conserv 136: 346-361.

Pearson RG, Raxworthy CJ, Nakamura M, Peterson AT (2007) Predicting species distributions from small numbers of occurrence records: a test case using cryptic geckos in Madagascar. J Biogeogr 34: 102-117.

Peppler-Lisbach C, Schröder B (2004) Predicting the species composition of Nardus stricta communities by logistic regression modelling. J Veg Sci 15: 623-634.

Phillips SJ, Anderson RP, Schapire RE (2006) Maximum entropy modeling of species geographic distributions. Ecol Model 190: 231-259. Software available on: http://www.cs.princeton .edu/ schapire/maxent.
Phillips SJ, Dudík M (2008) Modeling of species distributions with Maxent: New extensions and a comprehensive evaluation. Ecography 31: 161-175.

Phitos D, Strid A, Snogerup S, Greuter W (eds) (1995) The Red Data Book of Rare and Threatened Plants of Greece. W.W.F., Athens.

Pillon Y, Chase M (2006) Taxonomic exaggeration and its effects on orchid conservation. Conserv Biol 21: 263-265.

Rasmussen HN (1995) Terrestrial orchids from seed to mycotrophic plant. Cambridge University Press, Cambridge.

Renz J (1930) Beiträge zur Orchideenflora der insel Kreta. Repert Spec Nov Regni Veg 28: 241-262.

Renz J (1932) Die Orchideenflora von Ostkreta (Sitia). Repert Spec Nov Regni Veg 30: 97-118.

Sólymos P, Fehér Z (2005) Conservation prioritization based on distribution of land snails in Hungary. Conserv Biol 19: 1084-1094.

Stewart J (1992) The conservation of European orchids. Nature and environment, No. 57. Council of Europe, Strasbourg.

Strid A, Tan K (eds) (1997) Flora Hellenica Vol. 1. Koeltz Scientific Books, Germany.

Swarts ND, Dixon KW (2009) Terrestrial orchid conservation in the age of extinction. Ann Bot 104: 543-556.

Thanos CA, Fournaraki C, Georghiou K, Dimopoulos P, Bergmeier E (2005) A Pilot Network of Plant Micro-Reserves in Western Crete. Book of Abstracts, XVII International Botanical Congress, July 17-23, 2005, Vienna, Austria pp 598.

Thiele G, Thiele W (2010) Unsere Orchideen-Fundorte in Europa. Jour Eur Orch 42(2): 333-411.

Tsiftsis S, Tsiripidis I, Karagiannakidou V (2009) Identifying areas of high importance for orchids conservation in east Macedonia (NE Greece). Biodiv Conserv 18: 1765-1780.

Tsiftsis S, Tsiripidis I, Karagiannakidou V, Alifragis D (2008) Niche analysis and conservation of the orchids of east Macedonia (NE Greece). Act Oecolog 33: 27-35.

Vakhrameeva MG, Tatarenko IV, Varlygina TI, Torosyan GK, Zagulski MN (2008) Orchids of Russia and adjacent countries (within the borders of the former USSR). ARG Gantner Verlag KG, Ruggell/Liechtenstein.

van der Cingel NA (1995) An atlas of orchid pollination. European orchids. AA Balkema, Rotterdam.

Vogiatzakis IN, Griffiths GH, Mannion AM (2003) Environmental factors and vegetation composition, Lefka Ori massif, Crete, S. Aegean. Global Ecol Biogeogr 12: 131-146.

Warren DL, Glor RE, Turelli M (2010) ENMTools: a toolbox for comparative studies of environmental niche models. Ecography 33: 607-611.

Warren DL, Seifert SN (2011) Ecological niche modeling in Maxent: the importance of model complexity and the performance of model selection criteria. Ecol Appl 21(2): 335-342.

Williams PH, Gibbons D, Margules C, Rebelo A, Humphries CJ, Pressey R (1996) A comparison of richness hotspots, rarity hotspots and complementary areas for conserving diversity using British birds. Conserv Biol 10: 155-174.

Williams PH, Margules CR, Hilbert DW (2002) Data requirements and data sources for biodiversity priority area selection. J Biosci 27: $327-338$

Wilson AK, Cabeza M, Klein CJ (2009) Fundamental concepts of spatial conservation prioritization. In: Moilanen A, Wilson AK, Possingham HP (eds) Spatial conservation prioritization. Quantitative methods and computational tools. Oxford University Press Inc., New York, pp 16-27.

Zaffran J (1990) Contributions à la flore et à la vegétation de la Crète. Universitè de Provence, Aix en Provence. 